\title{
Membaca Al Fatihah Reflektif Intuitif untuk Menurunkan Depresi dan Meningkatkan Imunitas
}

\author{
Very Julianto ${ }^{1}$ \\ PS Psikologi Fakultas Ilmu Sosial dan Humaniora \\ UIN Sunan Kalijaga Yogyakarta \\ Subandi ${ }^{2}$ \\ Fakultas Psikologi Universitas Gadjah Mada
}

\begin{abstract}
This study aimed to reduce depression and increase immunity through training of reading of the reflective intuitive Al-Fatihah. Researchers used an experimental method with pretest-posttest control group design. Each experimental group and control group consisted of 10 students of Islamic Boarding School. To measure stress degree, Depression Anxiety Stress Scale (DASS) was used. Immunity was measured with microscopic slide method using hematology analyzer. Quantitative analysis was done through a mixed design anova statistical test. The results showed that the training could reduce depression $(F=15.34, p<0.05)$ and increase immunity $(F=25.6, p<0.05)$. This study defines that Reading of Reflective Intuitive $\mathrm{Al}$ Fatihah can change a subject's perception toward any problem of life. The subjects of this research could see what was going on in their lives through the anchor perspective. The experimental subjects who had secured their anchors onto Allah could significantly decrease their depression and improve their immunity. Such state of calmness cannot be separated from Quran reading.
\end{abstract}

Keywords: Al Quran, imun system, stress

Abstrak. Penelitian ini bertujuan untuk menurunkan depresi dan meningkatkan imunitas melalui pelatihan membaca Al Fatihah reflektif intuitif. Peneliti menggunakan metode eksperimen dengan pretest-posttest control group design. Kelompok eksperimen dan kelompok kontrol masing-masing terdiri dari 10 siswa pondok pesantren. Pengukuran tingkat stres menggunakan Depression Anxiety Stress Scale (DASS) dan pengukuran imunitas menggunakan alat hematology analyzer dengan metode slide mikroskopis. Analisis kuantitatif menggunakan mixed design anova. Hasil penelitian menunjukkan bahwa membaca Al Fatihah reflektif intuitif dapat menurunkan depresi $(F=15.34, p<0.05)$ dan meningkatkan imunitas $(F=25.6, p<0.05)$. Penelitian menunjukkan bahwa membaca Al Fatihah reflektif intuitif dapat mengubah persepsi subjek terhadap permasalahan dalam hidupnya. Subjek mulai melihat apa yang sedang terjadi pada diri mereka dengan menggunakan perspektif anchor Allah. Subjek eksperimen yang berhasil memegang teguh anchor Allah, mengalami penurunan depresi dan peningkatan imunitas secara signifikan. Perubahan tersebut tidak dapat dipisahkan dari rasa tenang sesudah membaca Al Quran.

Kata kunci: Al Quran, sistem imunitas, stres

\footnotetext{
${ }^{1}$ Korespondensi mengenai artikel ini dapat melalui: very_psi@mail.ugm.ac.id

2 Atau melalui: subandi@ugm.ac.id
} 
Masa remaja adalah masa dimana seorang individu banyak menghadapi peristiwa penuh stresor dalam kehidupan sehari-hari. Masalah-masalah tersebut menyebabkan remaja menjadi rentan mengalami gangguan psikologis seperti stres, ketakutan, kecemasan, agresivitas dan melarikan diri pada perilaku maladaptif (Schneiders, 1964; Booker, 2004). Perubahan yang terjadi menuntut individu menyesuaikan diri terhadap tuntutan dan tugas-tugas perkembangan mereka (Rathus \& Nevid, 2002). Perubahan itu terjadi pada aspek fungsional individu seperti fisik, psikologis dan sosial (Finkelstein, 2004; Booker, 2004). Remaja belum memiliki pegangan (anchor) dalam hidupnya. Hal ini dikarenakan remaja sedang mencari jati dirinya. Seorang remaja akan menjadikan pegangan hidupnya untuk menjaga kestabilan dan mencapai keseimbangan dalam hidupnya. Anchor yang paling abstrak adalah Allah. Anchor Allah tidak bisa terbayangkan sehingga hanya dapat diamati dari manifestasi dalam bentuk virtues atau prinsip-prinsip kehidupan. Melalui virtues ini individu dapat menghayati makna anchor Allah (Riyono, 2012).

Kondisi kehidupan remaja yang penuh dengan perubahan, tuntutan, ketidakpastian dan harapan menjadikan kejadian dalam hidupnya akan dimaknai secara subjektif. Perbedaan subjektif ini yang disebut dengan individual differences. Perbedaan tersebut tergantung bagaimana individu mempersepsikan sesuai dengan anchor-nya (Riyono, 2012). Remaja juga belum sepenuhnya memiliki pegangan terutama dalam hal spiritualitas dan religiusitas karena mereka sedang tahap keimanan individuasi-reflektif.

Depresi adalah gangguan mood yang berasal dari hilangnya kendali terhadap perasaannya dan adanya pengalaman subjektif terhadap suatu hal yang dianggapnya sebagai suatu penderitaan yang berat. Biasanya penderita depresi akan merasa kehilangan energi, minat dan nafsu makan. Penderita depresi juga akan kesulitan berkonsentrasi, adanya perasaan bersalah dan berfikir kearah kematian atau bunuh diri (Kaplan \& Sadock, 1997; Atkinson 1991).

Depresi dapat merusak sistem hypothalamic-pituitary-adrenocortical (HPA). Hal ini dapat meningkatkan kadar kortisol dalam darah dan perubahan sekresi ACTH (Parker dkk, 2003). Perubahan sistem endokrin dalam tubuh penderita depresi dapat berakibat menurunnya imunitas dalam tubuh mereka. Imunitas adalah sebuah sistem perlindungan tubuh dari sakit terutama sakit yag diakibatkan infeksi. Imun yang bereaksi dan bekerja sama untuk melawan substansi asing disebut dengan respons imun (Abbas, 2000; Herowitz, 1993).

Studi terbaru menunjukkan bahwa turunnya kemampuan imunitas diakibatkan adanya gangguan psikologis yang dapat ditinjau dari aspek religiusitas (Mustamir, 2007; Ong, 2006; Rezaei, 2008; Kiyani, 2011). Belzen (dalam Chizanah 2011) menyatakan bahwa religiusitas berkaitan dengan kekuatan yang lebih tinggi (Tuhan), kegiatan-kegiatan keagamaan dan keyakinan yang mendasarinya. Religiusitas memberikan pengaruh positif dalam masa penyembuhan dan rehabilitasi (Kane, 2006).

Penelitian Khan (2010) menunjukkan bahwa membaca Al Quran dengan menggunakan visualisasi dan sistem multimedia dapat memberikan relaksasi, menghilangkan kebosanan, kelelahan, depresi dan stres. Efek pembacaan Al Quran tersebut akan bersifat permanen dan bertahan lama ketika dilakukan setiap hari secara rutin dan terus-menerus. 
Dalam Al Quran terdapat banyak kandungan nilai seperti tentang keimanan, ibadah, ilmu pengetahuan, tentang kisahkisah tertentu, filsafat, dan juga ada sebagai tata hubungan manusia sebagai makhluk individu maupun makhluk sosial (Najati, 1985). Kandungan dalam Al Quran dapat diharapkan menjadi motivasi dan penyemangat bagi penderita depresi yang sedang putus asa. Kandungan Al Quran dapat direpresentasikan dalam surat $\mathrm{Al}$ Fatihah.

Surat Al Fatihah adalah ayat yang paling populer dan paling dihafal dikalangan umat muslim. Bahkan membaca $\mathrm{Al}$ Fatihah menjadi syarat sahnya sholat bagi kaum muslimin. Hal ini menunjukkan betapa tingginya kedudukan surat Al Fatihah ini (Ad-Dimasyqi, 2000). Kedudukan tersebut dapat dilihat dari nama lain dari Surat Al Fatihah seperti Fatihatul Kitab dan Ummul kitab atau Ummul Quran. Fatihatul Kitab merujuk penempatan Surat Al Fatihah sebagai surat pertama dalam penyusunan Al Quran. Al Fatihah memiliki sebutan sebagai Ummul Kitab yang artinya induk dari seluruh Al Quran. Hal ini dikarenakan didalam surat Al Fatihah terkandung seluruh pokok ajaran dan nilai yang terkandung dalam Al Quran (AdDimasyqi, 2000).

Dalam membaca Al Fatihah harus dilakukan secara tartil atau membaca dengan benar dan paham dengan makna yang terkandung (Iim, 2003). Pengertian tartil dalam membaca Al-Quran bermakna pelan-pelan dan perlahan-lahan, membaca huruf dan harakatnya dengan jelas (Al Qaradhawi, 2007). Craik dan Lochart (dalam Matlin, 1998) menyatakan bahwa informasi akan cenderung diingat apabila level pemrosesannya bersifat dalam, dibandingkan dengan jika diproses secara dangkal. Hal ini menunjukkan bahwa Surat Al Fatihah akan lebih diingat apabila pembacaanya tidak hanya membaca ayatnya tapi juga mengetahui kandungan makna didalamnya.

Membaca Al Fatihah Reflektif Intuitif sendiri pada dasarnya adalah membaca Al Quran yang direfleksikan dalam dirinya secara berulang-ulang. Hal ini dapat memberikan motivasi dan pemahaman dari pembacanya, dalam hal ini penderita depresi, mengenai pandangan terhadap pegangan hidupnya. Diharapkan mereka dapat meneguhkan pegangan hidupnya (anchor) mereka kepada Allah. Ketika sudah membaca Al Fatihah maka mereka dapat mengembalikan semua hal yang terjadi dalam hidupnya kedalam ketentuan Allah. Mereka juga tidak lagi merasa berputus asa dan memahami janji dan ketentuan Allah dari Surat Al Fatihah yang mereka baca. Membaca Al Quran, Sholat dan Doa dapat menjadikan seseorang berbuat sesuai dengan yang ia bacakan (Sholeh, 2006).

Ketika penderita depresi sudah memiliki semangat hidup dan stresor kehidupannya telah dimaknai positif maka akan direspons oleh hipotalamus. Imunitas yang tadinya terganggu akibat rusaknya keseimbangan sistem endrokin menjadi terkontrol karena hipotalamus mensekresi realising hormone. Realising hormone ini berfungsi merangsang sistem endokrin yang dapat mengontrol kerja kelenjar hipofisis (Lutgendorf, 2003; Abbas, 2000). Kelenjar Hipofisis yang dikontrol tersebut akan mengurangi sekresi hormon ACTH sehingga kelenjar sasaran tidak mensekresi hormon kortisol (Abbas, 2000).

Menurut Block dan Mead (dalam Widedosari, 2007) bahwa hormon kortisol akan menjadi imunodepresi bagi sistem imun manusia. Imunodepresi atau imunosupresor adalah mekanisme untuk menghambat atau menekan aktivitas sistem 
imun. Ketika stresor dimaknai dengan distress maka akan mengurangi sekresi hormon kortisol. Hormon ini kemudian menekan aktivitas sel $\mathrm{T}$ (Freeman \& Lawlis, 2001). Itu berarti sistem kerja imun ditekan atau terhambat.

Penelitian ini akan mengambil indikator imunitas berupa jumlah neutrofil. Neutrofil dikenal sebagai sel mediator inflamasi yang utama dalam sistem imun. Neutrofil memiliki mekanisme regulasi untuk mengontrol daerah inflamasi. Penelitian sebelumnya menunjukkan bahwa neutrofil berperan terhadap stress oksidatif dan inflamasi pada perokok (Abbas, 2000).

Berdasarkan paparan yang telah diberikan maka peneliti merancang sebuah model membaca Al Fatihah reflektifintuitif. Diharapkan membaca reflektifintuitif dengan memahami makna dan menghayatinya dapat memberikan motivasi dan pemahaman dari penderita depresi mengenai pandangan terhadap pegangan hidupnya. Diharapkan mereka dapat meneguhkan pegangan hidup (anchor) mereka kepada Allah. Dengan demikian kejadian yang mereka alami dalam kehidupannya akan dinilai lebih positif dan membuat jiwa menjadi tenang sehingga tidak menganggu keadaan homeostatis dalam diri. Hipotesis penelitian adalah membaca Al Fatihah reflektifintuitif dapat menurunkan depresi dan meningkatkan status imunitas.

\section{Metode}

\section{Subjek Penelitian}

Subjek penelitian ini berjumlah 20 orang dengan kriteria sebagai berikut: (1) Skor stres sedang, tinggi dan sangat tinggi; (2) Jenis kelamin wanita; (3) Umur 16-18 tahun dan berpendidikan SMA; (4) Status ekonomi menengah kebawah; (5) Rutin membaca Al Quran minimal 1 hari 1 halaman; (6) Memiliki kemampuan memahami arti ayat Al Quran, dan (7) Kesamaan fase menstruasi.

\section{Instrumen Penelitian}

Penelitian ini menggunakan instrumen DASS sub tes depresi untuk mengukur depresi. Beberapa penelitian sudah menggunakan instrumen DASS dan hasilnya DASS valid dan reliabel sebagai alat ukur (Rahmawati, 2008; Isnaeni, 2010; Imam, 2008; Henry, 2003). Peneliti juga melakukan uji coba dengan hasil yang dianalisis menggunakan koefisien Cronbach's alpha $(\alpha)$. hasilnya menunjukkan bahwa DASS valid dan reliabel dengan koefisien 0,888. Pengukuran imunitas dengan menggunakan metode hematology analyser. Metode ini digunakan untuk menghitung sel neutrofil dalam darah.

\section{Desain Penelitian}

Penelitian ini menggunakan rancangan Pretest-Postest Control Group Design. Rancangan tersebut akan menguji efek suatu perlakuan terhadap variabel dependen dengan cara membandingkan keadaan variabel dependen pada kelompok eksperimen sebelum dan setelah perlakuan (Shaugnessy, 2006).

\section{Prosedur Penelitian}

Subjek penelitian dikelompokkan menjadi dua kelompok dengan jumlah masing-masing kelompok 10 orang. Pengelompokan menggunakan random assignement dengan cara pengundian. Subjek yang sudah ditempatkan pada dua kelompok yang setara diberikan pretest untuk mengetahui kondisi stres dan imunitas pada masing-masing kelompok sebelum proses ekseperimen dimulai. Tes 
DASS sub tes stres dilakukan terlebih dahulu sebelum diberikan sampling darah.

Kelompok eksperimen mendapatkan pelatihan selama delapan sesi. Satu sesi digunakan untuk pengenalan membaca reflektif intuitif Al Fatihah. Tujuh sesi lainnya membahas mengenai ayat Al Fatihah sebanyak satu ayat tiap sesinya. Pada dasarnya pelatihan reflektif intuitif hampir sama seperti tilawah biasa. Perbedaannya terletak pada pemahaman makna yang direfleksikan kedalam diri dan penghayatan makna ayat yang dibaca. Reflektif adalah membaca dengan memahami makna ayat Al Fatihah yang dibaca. Pemahaman ilmu tersebut direfleksikan kedalam proses kehidupan yang subjek lalui selama ini. Proses intuitif adalah dengan merasakan makna Al Fatihah yang dibaca.

Persiapan sebelum memulai kegiatan membaca $\mathrm{Al}$ Fatihah reflektif intuitif meliputi kewajiban untuk mandi, makan dan berwudhu terlebih dahulu. Subjek kemudian diminta mengisi buku catatan hatiku untuk mengetahui apa yang dirasakannya saat ini dan persepsi subjek terhadap kehidupannya selama ini sebelum sesi pelatihan dimulai. Subjek sebelum membaca Al Fatihah diwajibkan untuk melaksanakan adab membaca seperti mengikhlaskan diri membaca Al Fatihah demi Allah SWT, beristighfar memohon ampun, tawadhu' atau merendahkan diri dan membaca doa sebelum memulai membaca Al Fatihah.

Subjek kemudian membaca Al Fatihah sebanyak tiga kali secara sendiri-sendiri dengan mengeluarkan suara. Subjek dapat memilih tempat yang membuat nyaman. Fasilitator kemudian menjelaskan makna Al Fatihah dan kemudian mengajak subjek untuk melakukan refleksi makna ayat $\mathrm{Al}$ Fatihah yang mereka baca kedalam proses kehidupan mereka. Fasilitator kemudian menjelaskan mengenai proses intuitif. Subjek diminta untuk merasakan makna ayat yang mereka baca.

Subjek kemudian membaca Al Fatihah kembali sebanyak tiga kali. Membaca Al Fatihah disertai dengan merefleksikan makna ayat Al Fatihah kedalam kehidupannya. Fasilitator memfasilitasi subjek untuk membaca Al Fatihah dengan menghayati ayat per ayat dari surat yang mereka baca.

Subjek kemudian mengisi buku catatan hatiku. Pemberian buku catatan hatiku untuk melihat apakah ada perubahan perasaan dan persepsi subjek setelah mengikuti sesi ini. Fasilitator kemudian mengingatkan kewajiban subjek untuk membaca Al Fatihah secara reflektif

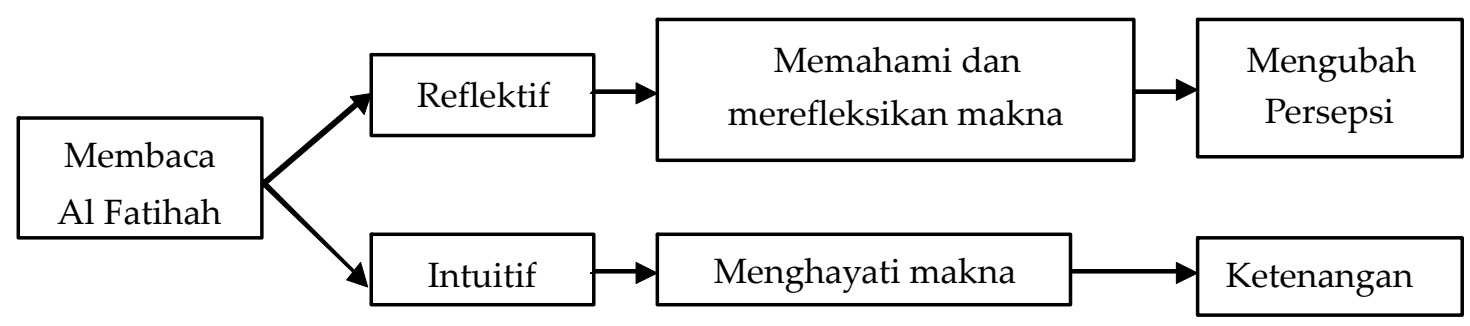

Gambar 1. Pelatihan Membaca Al Fatihah Reflektif Intuitif

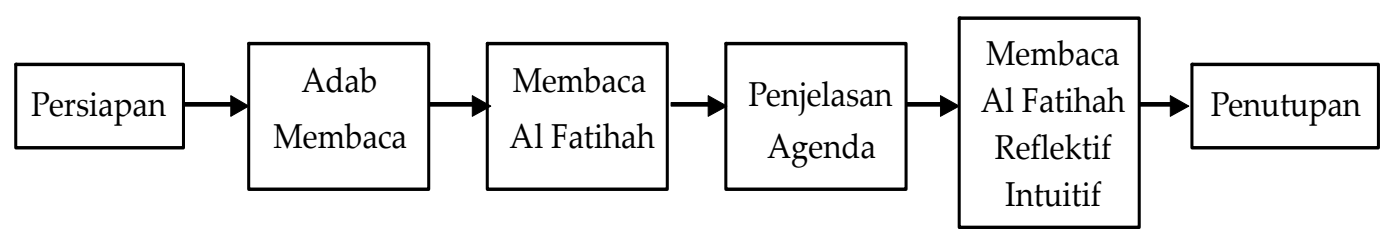

Gambar 2. Prosedur Pelatihan 
intuitif sebanyak 10 kali sesudah Maghrib, Isya, dan Subuh. Setiap kali selesai membaca Al Fatihah setelah sholat, subjek diminta untuk mengisi buku kontrol dan menceritakan apa yang ia rasakan saat itu.

Posttest segera diberikan setelah sesi terakhir terlaksana. Posttest digunakan untuk mengetahui kondisi subjek setelah pelatihan. Subjek eksperimen dan kontrol diberikan posttest DASS sub tes stres dan sampling darah. Data yang terkumpul kemudian dianalisis oleh peneliti.

\section{Analisis}

Analisis kuantitatif yang digunakan dalam penelitian ini adalah mixed design analisis varians (anova). Mixed design anova dipilih karena dapat membandingkan skor pretest dan posttest pada kelompok eksperimen dan kelompok kontrol dan membandingkan skor dua kelompok (Field, 2005). Analisis kualitatif berbentuk deskriptif naratif dilakukan terhadap hasil buku catatan hatiku dan hasil observasi.

\section{H a s i 1}

\section{Deskripsi Subjek Penelitian}

Data sosiodemografi subjek penelitian mencakup deskripsi karakterisik subjek penelitian, disajikan pada Tabel 1 . Berdasarkan Tabel 1 terlihat bahwa subjek eksperimen berjumlah 20 orang. Kedua puluh orang tersebut berasal dari kategori remaja akhir yang berasal dari kelas 1 dan kelas 2 SMA.

\section{Deskripsi Data Penelitian}

Deskripsi data penelitian disajikan untuk mengetahui karakteristik data pokok yang berkaitan dengan penelitian yang dilakukan (lihat Tabel 2).

Skor depresi kelompok eksperimen sebelum perlakuan memiliki skor rata-rata 17,3 dengan $S D$ 3,802. Skor depresi mengalami penurunan sehingga skor rata-rata menjadi 10,8 dengan $S D$ 4,984. Skor imunitas kelompok eksperimen sebelum perlakuan memiliki skor rata-rata 4,37 dengan $S D$ 1,36. Skor imunitas mengalami

Tabel 1

Deskripsi Karakteristik Subjek Penelitian

\begin{tabular}{lcc}
\hline Karakteristik & Rincian (n) & Persentase (\%) \\
\hline Usia & 8 & \\
$\mathbf{1 6}$ & 9 & 40 \\
$\mathbf{1 7}$ & 3 & 45 \\
$\mathbf{1 8}$ & & 15 \\
Pendidikan & 13 & \\
Kelas 1 SMA & 7 & 65 \\
Kelas 2 SMA & & 35 \\
\hline
\end{tabular}

Tabel 2

Data Kuantitatif

\begin{tabular}{lcccccccc}
\hline \multirow{2}{*}{ Skor } & \multicolumn{4}{c}{ Eksperimen } & \multicolumn{5}{c}{ Kontrol } \\
\cline { 2 - 9 } & Mean & SD & Max & Min & Mean & SD & Max & Min \\
\hline DepresiPre & 17,3 & 3,802 & 23 & 13 & 17,4 & 3,777 & 21 & 13 \\
DepresiPost & 10,8 & 4,984 & 22 & 6 & 20,1 & 3,984 & 24 & 11 \\
NeutPre & 4,37 & 1,36 & 6,8 & 2,5 & 5,17 & 1,45 & 7,2 & 2,7 \\
NeutPost & 5,28 & 1,35 & 7,5 & 3,1 & 4,59 & 1,19 & 6,5 & 3,1 \\
\hline
\end{tabular}


peningkatan sehingga skor rata-rata menjadi 5,28 dengan $S D$ 1,35.

Skor depresi kelompok kontrol sebelum perlakuan memiliki skor rata-rata 17,4 dengan $S D$ 3,777. Skor depresi mengalami peningkatan sehingga skor rata-rata menjadi 20,1 dengan $S D$ 3,984. Skor imunitas kelompok kontrol sebelum perlakuan memiliki skor rata-rata 5,17 dengan $S D$ 1,45. Skor imunitas mengalami peningkatan sehingga skor rata-rata menjadi 4,59 dengan $S D$ 1,19.

Grafik varians dapat dilihat dari Gambar 3.

Verifikasi Asumsi Normalitas dan Homogenitas

Analisis untuk verfikasi normalitas menggunakan Kosmolgorov-Smirnov. Veri-
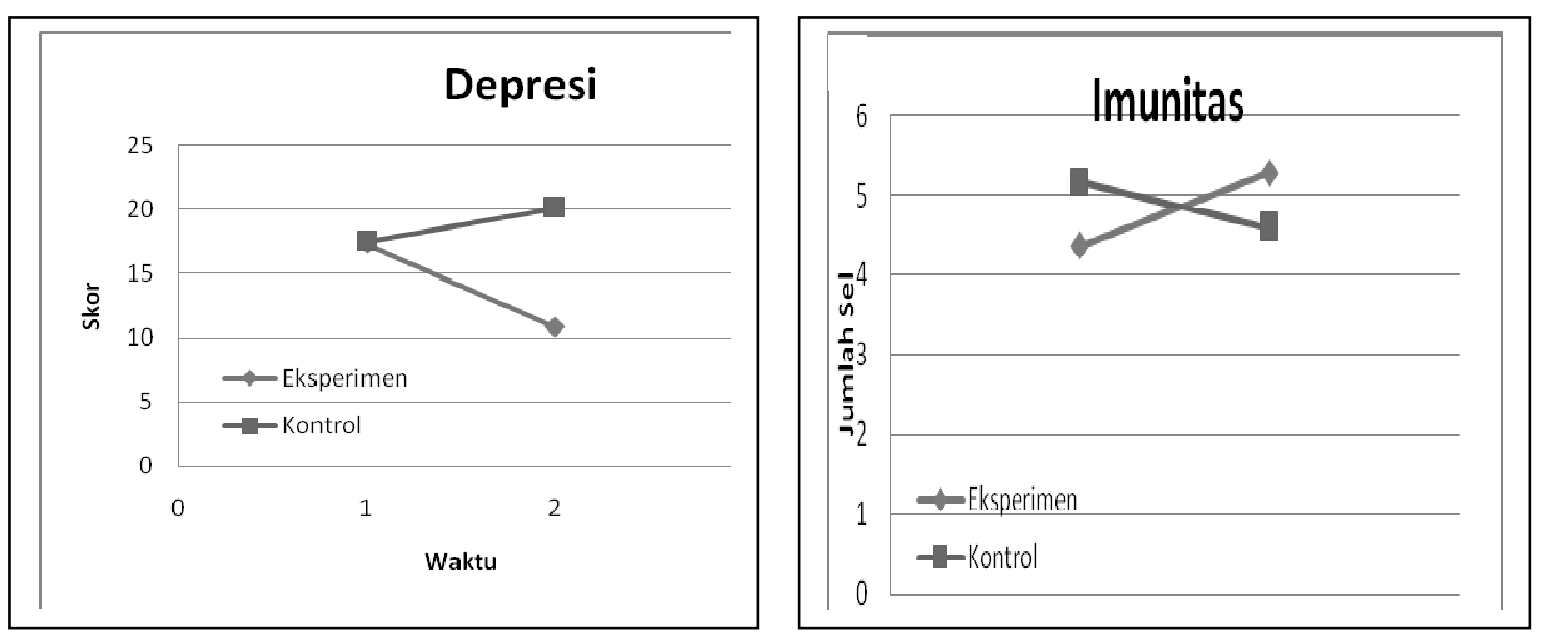

Gambar 3. Grafik Varians

Tabel 3

Uji Normalitas

\begin{tabular}{llcccc}
\hline \multirow{2}{*}{ Kelompok } & \multirow{2}{*}{ Tes } & \multicolumn{3}{c}{ Kosmolgorov-Smirnov } \\
\cline { 3 - 6 } & & \multicolumn{2}{c}{ Depresi } & \multicolumn{2}{c}{ Imunitas } \\
\cline { 3 - 6 } & & Statistik & $\mathbf{P}$ & Statistik & $\mathbf{P}$ \\
\hline \multirow{2}{*}{ Eksperimen } & Pre test & 0,207 & $0,200^{*}$ & 0,178 & $0,200^{*}$ \\
& Post test & 0,184 & $0,200^{*}$ & 0,207 & $0,200^{*}$ \\
\hline \multirow{2}{*}{ Kontrol } & Pre test & 0,259 & $0,056^{*}$ & 0,226 & $0,158^{*}$ \\
& Post test & 0,189 & $0,200^{*}$ & 0,228 & $0,151^{*}$ \\
\hline
\end{tabular}

Ket: ${ }^{*}=$ normal 
Tabel 4

Ringkasan Hasil Analisis Varian Depresi dengan Mixed Design

\begin{tabular}{lllllll}
\hline Sumber Variasi & $J K$ & $\mathbf{D} \boldsymbol{R K}$ & $\boldsymbol{F}$ & Sig & ETA $^{2}$ \\
\hline $\begin{array}{l}\text { Dalam Kelompok } \\
\text { Amatan }\end{array}$ & 36,10 & 1 & 36,10 & 2,617 & 0,123 & 0,127 \\
Amatan Kelompok & 211,600 & 1 & 211,600 & 15,340 & 0,001 & 0,460 \\
\hline Antar Kelompok & & & & & & \\
Kelompok & 110,450 & 1 & 110,450 & 10,555 & 0,004 & 0,370 \\
\hline
\end{tabular}

Keterangan: JK=Jumlah Kuadrat; db=derajat kebebasan; RK=Rerata Kuadrat; F=Nilai F; $\mathrm{Eta}^{2}=$ sumbangan efektif Membaca Al Quran Reflektif Intuitif terhadap stres

Tabel 5

Perubahan Skor Depresi

\begin{tabular}{lcccc}
\hline \multicolumn{1}{c}{ Group } & Time & Time & Mean Difference & Sig \\
\hline Eksperimen & 1 & 2 & 6,5 & 0,001 \\
Kontrol & 1 & 2 & $-2,7$ & 0,121 \\
\hline
\end{tabular}

Dari Tabel 5 dapat dilihat bahwa: (1) Terdapat interaksi antara skor depresi dan jenis kelompok penelitian ( $F=15,340 ; p<$ 0,05). Hal ini menunjukkan terdapat penurunan skor pretest ke posttes yang berbeda secara signifikan antara kelompok eksperimen dan kelompok kontrol. (2) Pada kelompok eksperimen mengalami penurunan skor depresi secara signifikan $(p<0,05)$ yakni sebanyak 6,5 poin. Pada kelompok kontrol tidak signifikan mengalami peningkatan skor depresi $(p>0,05)$ sebanyak 2,7 poin. (3) Intervensi berupa Membaca Al Quran Reflektif-Intuitif berpengaruh signifikan terhadap penurunan depresi pada pengukuran sesudah intervensi dengan sumbangan efektif sebesar $46 \%$.

Hasil analisis varians imunitas dapat dilihat dari Tabel 6 dan perubahan varian imunitas dapat dilihat dari Tabel 7.

Dari Tabel 7 dapat dilihat bahwa: (1) Terdapat interaksi signifikan antara imunitas dan jenis kelompok penelitian $(F=25,6 ; \quad p<0,05)$. Hal ini menunjukkan terdapat peningkatan skor pretest ke posttest yang berbeda secara signifikan antara kelompok eksperimen dan kelompok kontrol. (2) Pada kelompok eksperimen mengalami peningkatan imunitas secara signifikan $(p<0,05)$ yakni sebanyak 0,91 poin. Pada kelompok kontrol mengalami penurunan imunitas secara signifikan $(p<0,05)$ yakni sebanyak 0,58 poin. (3) Intervensi berupa membaca Al Quran reflektif-intuitif berpengaruh signifikan terhadap peningkatan imunitas pada pengukuran sesudah intervensi dengan sumbangan efektif sebesar $58,7 \%$.

\section{Diskusi}

Hasil menunjukkan bahwa pelatihan membaca Al Fatihah reflektif intuitif dapat menurunkan depresi. Subjek yang mengalami depresi merasa kehilangan kendali terhadap perasaannya dan adanya pengalaman yang subjektif terhadap suatu hal yang dianggapnya sebagai suatu penderitaan yang berat. Biasanya penderita depresi akan merasa kehilangan energi, minat dan nafsu makan. Penderita depresi juga akan kesulitan berkonsentrasi, adanya perasaan bersalah dan berfikir kearah 
JULIANTO \& SUBANDI

Tabel 6.

Ringkasan Hasil Analisis Varian Imunitas dengan Mix Design

\begin{tabular}{lcccccc}
\hline \multicolumn{1}{c}{ Sumber Variasi } & $J \boldsymbol{K}$ & $\boldsymbol{d} \boldsymbol{b}$ & $\boldsymbol{R K}$ & $\boldsymbol{F}$ & Sig & ETA $^{2}$ \\
\hline $\begin{array}{l}\text { Dalam Kelompok } \\
\text { Amatan }\end{array}$ & 0,274 & 1 & 0,274 & 1,256 & 0,277 & 0,065 \\
Amatan Kelompok & 5,550 & 1 & 5,550 & 25,6 & 0,000 & 0,587 \\
\hline $\begin{array}{l}\text { Antar Kelompok } \\
\text { Kelompok }\end{array}$ & 0,015 & 1 & 0,015 & 0,009 & 0,926 & 0,000 \\
\hline
\end{tabular}

Keterangan: JK=Jumlah Kuadrat; $d b=$ derajat kebebasan; $\mathrm{RK}=$ Rerata

Kuadrat; F=Nilai F; Eta $^{2}=$ sumbangan efektif Membaca Al

Quran Reflektif Intuitif terhadap imunitas

Tabel 7.

Perubahan Imunitas

\begin{tabular}{lcccc}
\hline \multicolumn{1}{c}{ Group } & Time & Time & Mean Difference & Sig \\
\hline Eksperimen & 1 & 2 & $-0,910$ & 0,000 \\
Kontrol & 1 & 2 & 0,580 & 0,012 \\
\hline
\end{tabular}

kematian atau bunuh diri (Kaplan \& Sadock, 1997; Atkinson 1991).

Pelatihan membaca Al Fatihah reflektif-intuitif dapat membantu subjek menemukan semangat dan mempersepsikan positif kejadian dalam hidupnya. Hal ini karena subjek selalu memandang kejadian dalam hidupnya dari sudut pandang pegangan (anchor) selain Allah. Saat depresi, subjek kehilangan anchor yang mereka andalkan selama ini. Subjek tidak bisa selamanya mengandalkan anchor lainnya seperti materi dan orang lain. Hanya anchor Allah yang bisa diandalkan. Kesalahan memposisikan anchor dapat menimbulkan ketidakstabilan psikologis (Riyono, 2012). Pelatihan ini berhasil membantu subjek anchor mereka melalui refleksi prinsip kebaikan Allah, cinta dan kasih sayang Allah selama ini kedalam proses kehidupannya selama ini.

Subjek juga merasa tenang, lebih segar, fokus dan bisa berkonsentrasi. Pelatihan ini karena adanya proses intuitif atau penghayatan terhadap makna yang terkandung dalam Al Fatihah. Hal ini karena proses formation retikularis dalam otak menjadi lebih cermat terhadap informasi yang masuk. Didalam Al Quran sendiri telah tertulis mengenai hal ini dalam surat Ar Rad ayat 28.

"(yaitu) orang-orang yang beriman dan hati mereka manjadi tenteram dengan mengingat Allah. Ingatlah, hanya dengan mengingat Allah-lah hati menjadi tenteram".

Penelitian ini menunjukkan terjadinya peningkatan imunitas subjek setelah pelatihan membaca Al Fatihah reflektif intuitif. Depresi dapat menekan sistem imun sehingga tidak mampu berkembang. Hal ini disebut dengan proses imunodepresi (Abbas, 2000). Imunodepresi terjadi karena meningkatnya kadar kortisol dalam darah yang diakibatkan gangguan depresi subjek. Indikator imunitas berupa Neutrofil dapat mengembangkan jumlah dan fungsinya sesuai dengan kondisi yang ia hadapi saat ini (Block \& Mead dalam Wiedosari, 2007). Ketika anchor hidup subjek adalah Allah maka subjek memiliki pegangan yang dapat diandalkan. Hal ini kemudian menimbulkan perasaan tenang dan memandang positif terhadap apa yang terjadi dalam hidupnya. 


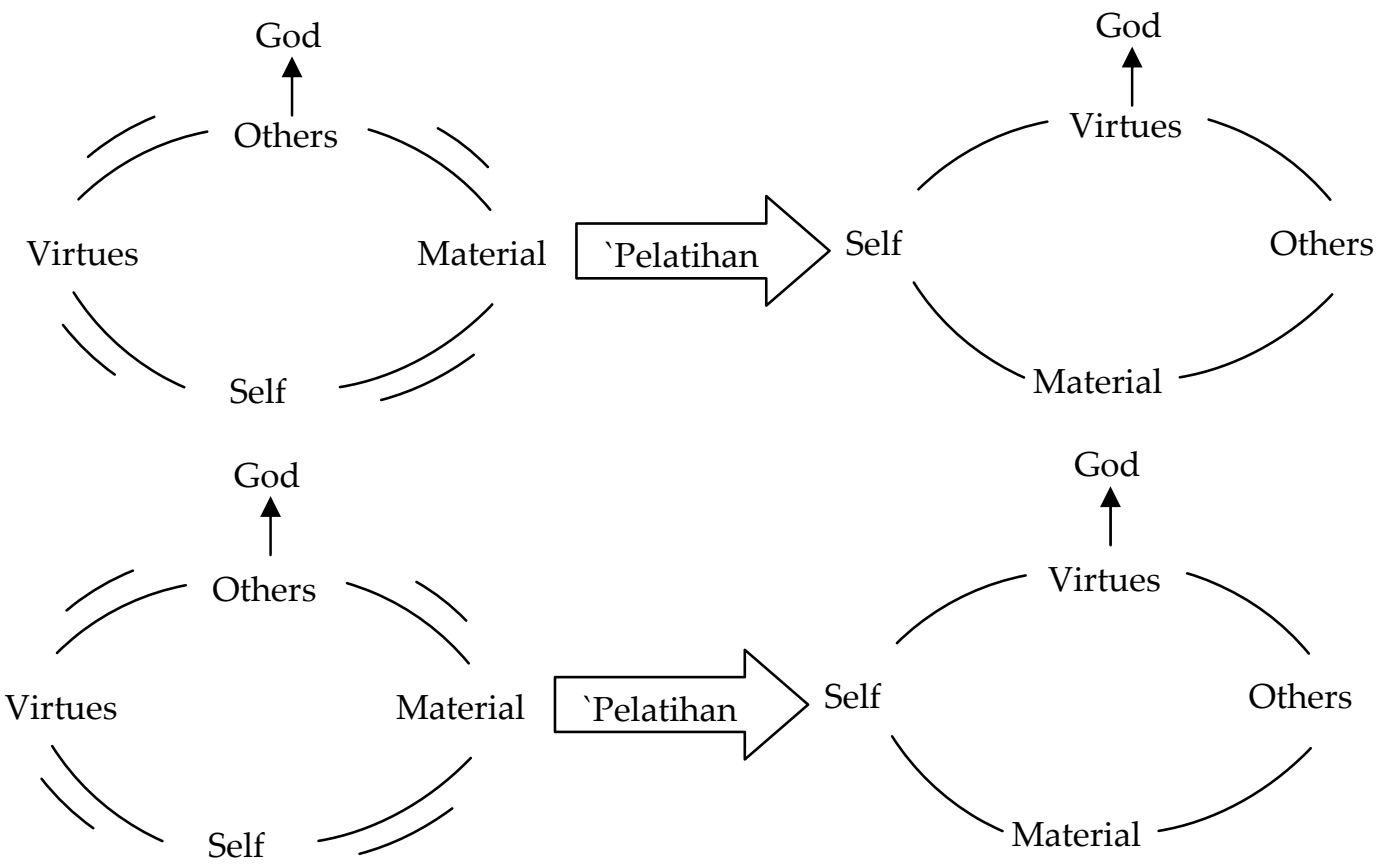

Gambar 4. Anchor subjek sebelum dan sesudah pelatihan

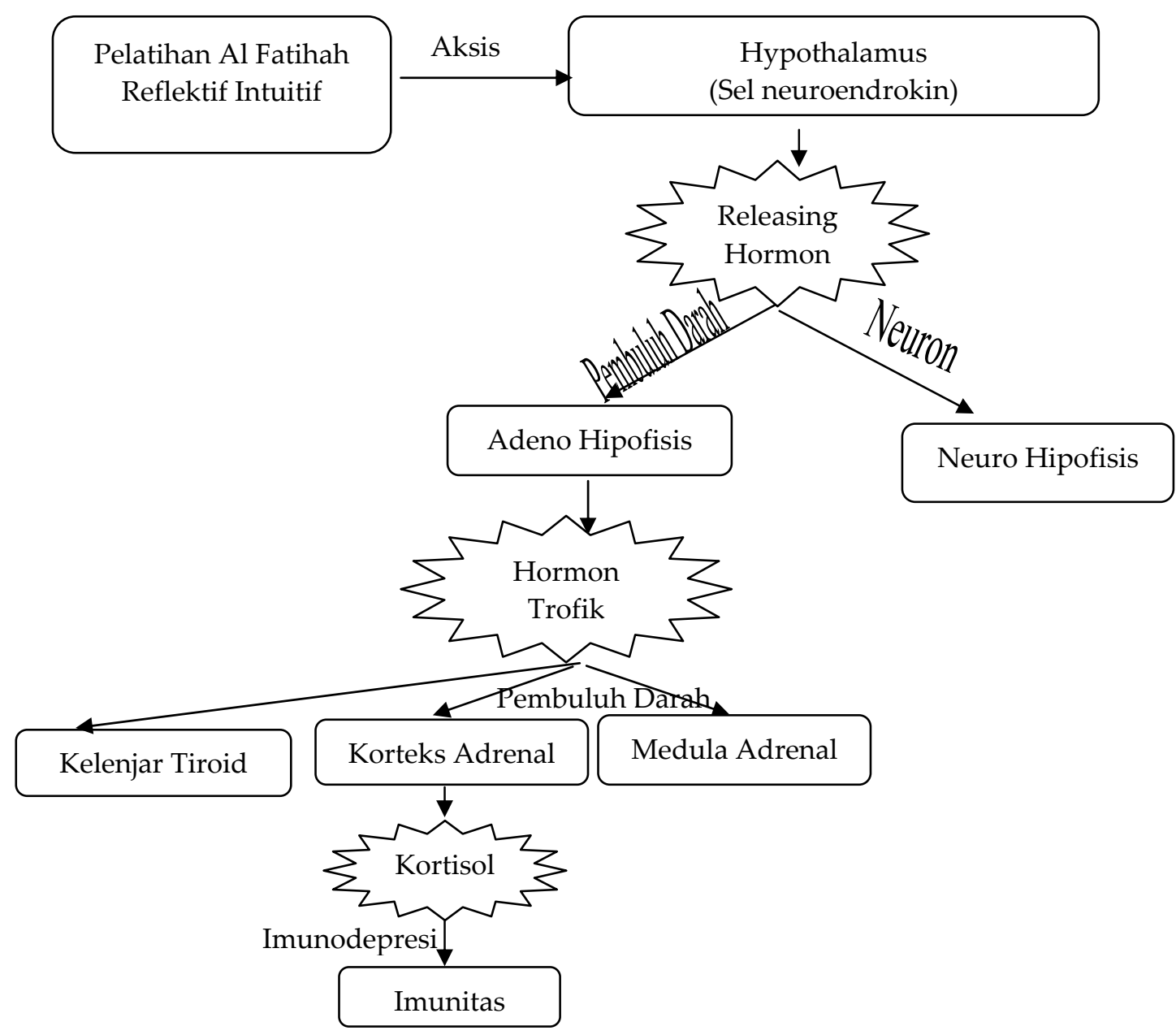

Gambar. 5. Pengaruh Pelatihan Al Fatihah Reflektif Intuitif Terhadap Imunitas 
Hal ini akan direspons oleh hipotalamus yang akan menghasilkan realizing hormone untuk merangsang sistem endokrin dan mengontrol kinerja kelenjar hipofisis (Lutgendorf, 2003; Abbas, 2000). Kelenjar hipofisis yang dikontrol tersebut akan mengurangi sekresi hormon ACTH sehingga kelenjar sasaran tidak mensekresi hormon kortisol (Abbas, 2000).

Pelatihan membaca Al Fatihah Reflektif Intuitif ini dapat melengkapi penelitian sebelumnya yang lebih banyak menekankan pada metode mendengarkan Al Quran seperti penelitian Mahdalena (2010). Secara neurologis membaca lebih memiliki efek dibandingkan hanya mendengarkan. Pada saat membaca maka Thalamus akan dipengaruhi melalui coliculus superior dan coliculus inferior. Pada saat mendengarkan maka Thalamus hanya dipengaruhi oleh satu coliculus (Abbas, 2000). Dengan dipengaruhinya Thalamus melalui dua coliculus tersebut membuat proses membaca $\mathrm{Al}$ Fatihah akan lebih terasa terhadap tubuh bila hanya mendengarkan Al Fatihah saja.

\section{Kesimpulan}

Hasil penelitian menunjukkan bahwa pelatihan Membaca Al Quran reflektif intuitif dapat menurunkan depresi secara signifikan dan meningkatkan imunitas melalui indikator jumlah Neutrofil. Perubahan signifikan depresi dan imunitas tidak terlepas adanya perubahan dalam persepsi subjek dalam memandang kejadian dalam hidupnya. Subjek mulai memandang apa yang terjadi dalam hidupnya dari sudut pandang anchor Allah. Subjek eksperimen yang berhasil meluruskan anchor-nya maka mengalami penurunan depresi dan peningkatan imunitas secara signifikan. Perubahan tersebut tidak terlepas adanya perasaan tenang setelah membaca Al Quran.
Penelitian ini dapat menjadi sebuah model alternatif dalam sistem pengajaran di pesantren. Diharapkan dengan adanya penelitian ini dapat meneguhkan anchor santri yang mayoritas masih remaja dan masih dalam tahap mencari jati diri. Penelitian ini dapat menjadi rujukan untuk menangani depresi. Peneliti selanjutnya dapat meningkatkan validitas eksternal dengan memperluas, memperbanyak jumlah subjek penelitian dan variasi ayat $\mathrm{Al}$ Quran yang dibaca.

\section{Kepustakaan}

Abbas, K. A. (2000). Cellular and molecular immunology (4th). Philadelphia: W.B. Saunders Company.

Ad-Dimasyqi, A. I. A. F. I. I. K. (2000). Tafsir ibnu katsir juz: al fatihah- al baqarah (Terjemahan). Bandung: Sinar Baru Algensindo.

Al-Qaradhawi, S. Y. (2007). Menumbuhkan cinta kepada Al-Quran. Yogyakarta: Mardhiyah Press.

Atkinson, R.L., Atkinson, R.C.,\& Hilgard, E.R. (1991). Pengantar Psikologi $8^{\text {th }} E d$. Jakarta: Erlangga.

Chizanah, L. (2011). Ikhlas = Proposional (Studi Komparasi Berdasar Caps). Jurnal Psikologi Islam, 8(2), 145-164.

Crawford, J. R., \& Henry, J. D. (2003). The Depression Anxiety Stress Scales (DASS): Normative data and latent structure in a large non-clinical sample. British Journal of Clinical Psychology 42, 111-131.

Field, A. (2005). Discovering statistics using SPSS. London: Sage Publications.

Finkelstein, D. M., Kubzansky, L. D., \& Goodman, E. (2006). Social status, stress, and adolescent smoking. Journal of Adolescent Health, 39, 678-685. 
Freeman, L., \& Lawlis, G. (2001). Mosby's complementary $\&$ alternative medicine : A research-based approach. St. Louis, MO: Mosby.

Henry, J. D., \& Crawford, J. R. (2005). The short-form version of the Depression Anxiety Stress Scales (DASS-21): Construct validity and normative data in a large non-clinical sample. British Journal of Clinical Psychology, 44, 227239. http:dx.doi.org/ 10.1348/014466505X29657.

Herowitz. (1993). Immunologi III. Yogyakarta: Gadjahmada University Press.

Iim, A. (2003). Pedoman ilmu tajwid lengkap. Bandung: CV Penerbit Diponegoro.

Imam, S. S. (2008). Depression Anxiety Stress Scales (DASS): Revisited. The 4th International Postgraduate Research Colloquium IPRC Proceedings.

Isnaeni, D. N. (2010). Hubungan antara stres dengan pola menstruasi pada mahasiswa D IV kebidanan jalur reguler Universitas Sebelas Maret. (Naskah tidak dipublikasikan), Fakultas Kedokteran, Universitas Sebelas Maret, Surakarta.

Kane, R. (2006). Hope beyond the hurt: Spirituality and the dual diagnosis of acquired brain injury and psychiatric disorder. Counselling, Psychotherapy, and Health, 1-19.

Kaplan, J. B., \& Sadock, T. C. (1997). Sinopsis Psikiatri (2 $\left.{ }^{\text {th }}\right)$. Jakarta: Binarupa Aksara.

Khan, N., Ahmad, N., Abdullah, A. A., \& Nubli, M. (2010). Mental and spiritual relaxation by recitation of the holy Quran. Second International Conference on Computer Research and Development. http://dx.doi/org/10.1109/ICCRD.2010. 62

Kiyani, R., Mohammadi, A., \& Pourahmad, E. (2011). Investigating the effect of prayer in increasing the mental health of college students. Procedia - Social and Behavioral Sciences, 30, 1875-1877. http://dx.doi.org/10.101

6/j.sbspro. 2011.10.364

Lutgendorf, S. K., \& Costanzo, E. S . (2003). Psychoneuroimmunology and health psychology: An integrative model. Brain, Behavior, and Immunity 17, 225232. http://dx.doi/org/10.1016/S08891591(03)00033-3

Mahdalena, Hammad, \& Endang. (2010). Pengaruh terapi Al Qur'an terhadap tingkat kecemasan dan imunitas pasien hospitalisasi di RSUD Ratu Zalecha Martapura. Jurnal Keperawatan dan Kebidanan (JIKK), 1(2), 62-69

Matlin, M. W. (1998). Cognition, (Ed $4^{\text {th }}$ ). Texas: Harcout Brace College Publisher Fort Worth.

Mustamir. (2007). Sembuh dan sehat dengan mu'jizat Al-Qur'an. Yogyakarta: Lingkaran.

Najati, M. U. (1985). Al Quran dan ilmu jiwa. Bandung: Penerbit Pustaka.

Nevid, J. S., Rathus, S. A., \& Greene, B. (2002). Psikologi Abnormal Jilid Dua (Ed 5). Jakarta: Erlangga.

Ong, A. D., Bergeman, C.S., Wallace, K.A., \& Bisconti, T. L. (2006). Psychological resilience, positive emotions, and successful adaptation to stress in later life. Journal of Personality and Social Psychology, 91(4), 730-749. http://dx. doi.org/10.1037/0022-3514.91.4.730730

Parker, M. L., Roff, L. D., Klemmack, L., Koenig H. G., Baker, P., \& Allman, R.M. (2003). Religiosity and Mental Health in Southern, Community Dwelling Older Adults. Journal of Aging and Mental Health, 7(5), 390-397.

Rezaei, M., Hajbaghery, M. A., Seyedfatemi, N., \& Hoseini, F. (2008). 
Complementary Therapies in Clinical Practice, 90-97. http://dx.doi.org/10. 1016/j.ctcp. 2008.01.001

Rahmawati, I., Haroen, H., \& Juniarti, N. (2008). Perbedaan tingkat stres sebelum dan sesudah terapi musik pada kelompok remaja di Panti Asuhan Yayasan Bening Nurani Kabupaten Sumedang. (Naskah tidak dipublikasikan), Fakultas Psikologi, Universitas Padjajaran, Bandung

Ramsey, P. H. (2007). Factorial design: Encyclopedia of measurement and statistic. Thousand Oaks: Sage Publication.

Riyono, B. (2012). Motivasi dengan perspektif psikologi islam. Sleman: Quality Publishing.
Schneiders, A. (1964). Personal adjustment and mental health. New York: Rinehart and Windston Inc.

Shaugnessy, J. J., Zechmeister, E. B., \& Zechmeister, J. S. (2006). Research methods in psychology. New York: McGraw Hill

Sholeh, M. (2006). Terapi sholat tahajud. Jakarta: Mizan Publikasi.

Wiedosari, E. (2007). Peranan imunomodulator alami (aloe vera) dalam sistem imunitas seluler dan humoral. (Naskah tidak dipublikasikan), Balai Besar Penelitian Veteriner, Bogor. 